\title{
Liberating reformed theology, social- embedded economics, and the white Afrikaans Reformed Churches
}

\author{
Pieters, Johan \\ University of KwaZulu-Natal \\ johanp@homonovus.co.za
}

\begin{abstract}
In this article, the author used a social-embedded framework to analyse the current economic paradigms of the white Afrikaans Reformed Churches in South Africa. He concluded that the current conventional paradigm is problematic in the lack of engagement with both the poor and alternative economic paradigms. He suggested that the notions of covenant, sovereignty and providence could assist the churches to develop an economic paradigm that is informed by solidarity with the poor. For this to happen he concludes that the churches need to develop a liberating hermeneutic in which the Bible is read as a book for the poor, while the readers remain conscious of their privileged position.
\end{abstract}

Key words

Economic paradigms; covenant; sovereignty; providence; poor; poverty

The idea of a self-adjusting market implied a stark utopia. Such an institution could not exist for any length of time without physically annihilating human community and the natural substance of society. ${ }^{1}$ [Karl Polanyi in The great transformation]

\section{Introduction}

To merge themes of a liberating Reformed theology, social-embedded economics into a contextual theology of economics will require more than

1 K Polanyi, The Great Transformation. The Political and Economic Origins of Our Time, (Boston: Beacon Press, 1944 [2001])), p. 3. 
the available space. However, we have to attempt it as much of the 'crying for life' in South Africa today is rooted in the economic circumstances of people and the way the economy is structured in South Africa. Thus, this paper can be no more than a theological reflection on how the predominantly white Afrikaans Reformed Churches could participate in establishing economic justice in South Africa.

There are not many decisions or and study documents about economics or the economy available from the white Afrikaans Reformed Churches. ${ }^{2}$ Based on enquiries and from what is available on the internet, only the Dutch Reformed Church (DRC) has produced a response to the ACCRAdeclaration (ACCRA) and most recently a discussion document on Economic Development. ${ }^{3}$ Both documents are part of a project launched in 2004 under the description of 'Prophecy on Profit'. The DRC and the GKSA published documents that deal with relevant topics such as poverty, land reform, provision of food and other necessities, as well as profiteering. In official documents the Churches often dealt with the economy as either a threat to continued existence of Church and congregations or as a moral and ethical responsibility. However, very little is done to critique the underlying social-economic structures. ${ }^{4}$ This paper attempts to engage the theological structures behind the economic position in mainly the DRC based on their response to ACCRA and the document on economic development. ${ }^{5}$

2 Based on responses from the church officials and material available on-line neither the GKSA, nor the NHK have produced official documents or standpoints with regard to the economy. The GKSA have not yet responded to my enquiry. On my enquiry with the NHK I received two documents, both minutes of the General Assembly of the church. The economy was mostly dealt with in the context of threat to church life and congregational survival and sustainability.

3 The document is entitled 'Die NG Kerk en die ekonomiese ontwikkeling van ons lande' [The DC and the economic development of our countries]. It is a discussion document and does not present an official Dutch Reformed Church position even though the last two sections contain statements that are formulated as if it represents provisional positions taken by the church leaders.

4 K. Tanner, Economy of Grace, (Minneapolis: Fortress Press, 2005), p. 3.

5 Ibid., p. 3. 


\section{The Dutch Reformed Church and the economy}

The position of the DRC could be described as a conventional, albeit critical, a conventional economic paradigm. The conventionalist position focuses on the conditions necessary for maximum economic growth that is best created by an economy structured without state intervention and regulations. ${ }^{6}$ The critical position is expressed in the rejection of neoliberalism in their decision about ACCRA. In the decision of the Synod, the alignment with ACCRA is built on an undertaking to act in solidarity with the poor, [to] resist consumerism, [to] cooperat[e] in development, [to] fight[] poverty, [to] promot[e] of family (social) relations, [to] research and 'live, teach and preach economic justice'. The rejection of neoliberal globalisation and its consequences has qualified this by refusing to 'demonise' people and institutions because they are part of the international trade system, adding that global capitalism is not the only cause of poverty and suffering or the divide between rich and poor. ${ }^{8}$

In the document on economic development a free market system 'where accumulation of wealth for shareholders is the aim of business' is rejected. ${ }^{9}$ The DRC leadership is well aware of the negative impact of the current economic system on the experience of human dignity, and even witnesses positively to the importance of the preferential option for the poor. ${ }^{10}$ The report also states that the workers of a company, their dependents, and communities all have an interest in the created wealth. Christians are called upon to build real relationships and to work with other communities to implement development programmes that address the adverse outcomes

6 N. Nattrass, "Controversies about Capitalism and Apartheid in South Africa: An Economic Perspective”, Journal of Southern African Studies 17, no. 4 (1991), p. 659.

7 NGKerk, 'Handelinge van die Algemene Sinode 2007,' (Pretoria: Nederduitse Gereformeerde Kerk, 2007), 112. The Church introduced the undertaking by declaring that ' $[w]$ e accept that the Gospel of Jesus excludes an uncritical and therefore irrational faith in the beliefs of neoliberal economic globalisation as set out in item 9 of the declaration of faith. We reject the accumulation of wealth at the expense of the poor. We care for the earth. We refuse to admire the powerful merely because they have power and we will not revere rich people just because they are rich. In this spirit we align ourselves with this declaration of faith ...'

8 NG Kerk, 'Algemene Sinode 2007,' p. 112.

9 NG Kerk, Die N.G. Kerk en die Ekonomiese Ontwikkeling van ons Lande (Pretoria: Nederduitse Gereformeerde Kerk, 2016), p. 10.

10 Ibid., p. 11. 
of the economic system such as exclusion from economic participation and income generation. ${ }^{11}$ This potentially revolutionary position is qualified by the statement that the current economic system must provide the resources to address the complex causes of poverty and inequality through economic growth. The argument is that a free market system is not the only cause of poverty and inequality and mere redistribution will not achieve anything. ${ }^{12}$ Already in 1994, the church placed their hope on economic growth when the General Synod called upon the membership of the church to pray for economic prosperity to alleviate poverty. ${ }^{13}$

The reason for this qualification is expressed in a process report from 2015. This report described the focus of the church as establishing a specific ethic and morality that is fundamental to a good economic society. ${ }^{14} \mathrm{~A}$ good economic society is described by concepts such as dignity, freedom, responsibility, prosperity, equality, participation, justice and sustainability. 15 These concepts refer to the results of the economic process without addressing the economic structures that should make the realisation thereof possible. We can conclude that the DRC is caught up in the tension between an economic paradigm that focuses on growth and non-intervention to establish a good life, and the need for an economic system that protects the poor, or a tension between unregulated freedom and solidarity.

\section{Social-embeddedness as new paradigm}

Hungarian economic historian, Karl Polany ${ }^{16}$ is best known for his critique of the 'free market' by employing the concept of the social-embeddedness of the economy. ${ }^{17}$ Social-embeddedness provides an analytical framework to

11 Ibid., p. 13.

12 Ibid., p. 10.

13 NG Kerk, „Besluiteregister van die Algemene Sinode 1994“ (Pretoria: Nederduitse Gereformeerde Kerk, 1994), p. 7.

14 NG Kerk, „Die N.G. Kerk en die ekonomie - 'n Prosesverslag“ (Pretoria Nederduitse Gereformeerde Kerk), accessed on 17 October, 8.

15 NG Kerk, 'Proses-verslag', p. 8.

16 Karl Polanyi is the elder brother of Michael Polanyi who is better known for his theoretical work in chemistry, economics and philosophy.

17 See the texts of F. Block and M. Somers, The Power of Market Fundamentalism: Karl Polanyi's Critique (Cambridge, Massachusettes: Harvard University Press 2014); and G. Dale, Karl Polanyi: The Limits of the Market (Cambridge; Malden, Mass.: Polity, 2010). 
answer questions about the impact of economic systems on communities. The reference point of embeddedness is not the economy as such, but 'the larger social systems in which all economies are located. ${ }^{18}$ Polanyi argued that throughout history the economic processes of production, distribution, and consumption were determined by the way systems of power and care were structured in the society the economy was located. Since social systems differ from one society to another, embeddedness should not be seen as an economic model or system.

Jens Beckert explained that for Polanyi the core meaning of embeddedness was twofold: First, he accepted that intervention in the economy through institutional regulations is unavoidable to protect the moral fabric of society against the motive of unrestricted competition and gain. ${ }^{19}$ Second, institutional regulations of the economic system should establish a democratic society. ${ }^{20}$ The aim is to ensure that everyone benefits from the economy to satisfy both the material and non-material needs and wants of all the members of society. ${ }^{21}$ Therefore representatives of the government producers, consumers, and workers share decision making on a local level according to specific mandates and negotiation processes. There is a third aspect of importance. The embeddedness of the economy protects the freedom of the lower classes by ensuring that nobody was excluded from access to livelihoods and prevented systemic famine and poverty. ${ }^{22}$

Polanyi's critique of the free market system is not the idea of a market as such, but that a free or self-regulating market requires unregulated markets for labour, land, and money. Labour and land, or human activity and nature are not commodities that were produced to be sold on the market and thus subjected to the supply and demand mechanism. The danger of the free market is that it 'subordinates the substance of society [that is human life]

18 J. Beckert, The Great Transformation of Embeddedness: Karl Polanyi and the New Economic Sociology, Discussion Paper 07/01 (Cologne: Max Planck Institute for the Study of Societies, 2007), p. 8.

19 Beckert, The Great Transformation of Embeddedness, p. 8.

20 Ibid., p. 8.

21 K. Polanyi, The Livelihood of Man, ed. Harry W. Pearson, (New York: Academic Press, 1977), 20.

22 Polanyi, The Great Transformation, 167. See also: A. Sen, Development as Freedom, (Oxford: Oxford University Press, 1999), p. 16. 
itself to the laws of the market ${ }^{23}$ or the impersonal mechanism of supply and demand. ${ }^{24}$ Polanyi concluded that an unregulated labour market undermined the freedom of the lower classes and exposed them to low wages, unemployment, family degradation, poverty caused by urbanisation and the destruction of the social support systems. If the creation of a labour market initiated processes of un-freedom, it was the establishment of a market for land, through land enclosures that created the conditions for a labour market. With the land enclosures it was no longer possible for many members of communities to till the earth and produce food. ${ }^{25}$ It left them with no other choice than to sell their labour to provide for themselves and their families. It also meant that labour costs now became an important part of production costs, and was subjected to the supply and demand mechanism of a self-regulating market. ${ }^{26}$

Instead of the Christian ethic of responsibility for one another, social structures became fractured and the economy became disembedded from the structures of care. ${ }^{27}$ Referring to Robert Owen, Polanyi added that this was indeed the point where European Christianity failed society by prioritising individualism above community. ${ }^{28}$ Land, labour and community were structures of care but became spaces of control and power through commodification. For Polanyi the commodification of land and labour is the origin of systemic poverty and famine, and of structural injustice. Un-freedom has economic roots.

A framework of social-embeddedness emphasises the integration of the economy into social contexts, responsibility and accountability in social relations and the need for access to livelihoods for all. When the integration of the economy into social contexts is compromised the freedom of the poor is also compromised. It highlights the tension between individual freedom or libertarian interests on the one hand, and social solidarity on

23 Polanyi, The Great Transformation, p. 75.

24 K. Polanyi, "The Economy as Instituted Process", in Trade and Market in the Early Empires, ed. Karl Polanyi, Conrad M. Arensberg, and Harry W. Pearson (Chicago: Free Press, 1957), pp. 249-50.

25 Polanyi, The Great Transformation, p. 36.

26 Polanyi, The Great Transformation, p. 75.

27 Ibid., p. 103.

28 Ibid., pp. 133 and 68. 
the other hand. Can the vision of freedom in Reformed theology resolve this tension?

\section{Liberating reformed theology}

It is well-known that Calvin identified three forms of freedom, i.e. freedom from the law, freedom from inner compulsion and freedom from external observation. ${ }^{29}$ Freedom from the law refers to being saved by grace alone. But this means that Christians no longer belong to themselves but to God and to one another. ${ }^{30}$ It calls for concrete actions of sacrifice in relationship with others to embody justice, and in relationship with God. ${ }^{31}$ Freedom from inner compulsion is irreducible, ${ }^{32}$ but is not an unconstrained freedom that could ignore the freedom of others. It indeed calls to resist the will to control, and to accept the responsibility of participating in society. Smit showed how freedom from inner compulsion exists in continuous tension with human partiality and finitude. ${ }^{33}$ The freedom from external observances is the freedom to act in resistance to subversive powers that institutionalise injustice and inequality. It has a critical function to call those who are 'spiritually free' to express their freedom in a life of consideration, obedience and activism. Reformed theology, thus, emphasises that freedom can only exist in community with fellow human beings. Polanyi argued that freedom in a complex society is paradoxical because personal freedom is embedded in community with others. ${ }^{34}$ On the basis of belonging to one another in Christ it is not possible for a liberating Reformed theology to separate spiritual freedom from temporal or concrete freedoms.

29 See: R. Boer, Political Grace. The Revolutionary Theology of John Calvin, (Louisville: Westminster John Knox Press, 2009), p. 125. See also: D.J. Smit, "Freedom in Belonging?" in Essays on Being Reformed. Collected Essays 3, ed. Robert Vosloo, Study Guides in Religion and Theology 14. Publications of the University of the Western Cape (Stellenbosch: SUN MeDIA, 2009), pp. 126-7.

30 Smit, 'Freedom', p. 125.

31 See: Ibid., p. 124.

32 Ibid., p. 128.

33 Ibid., p. 128.

34 B.J. Pieters, "Community and the Economy: A Reformed Theological Reflection on a Social-embedded Economy” (Ph D, University of KwaZulu-Natal, 2016), p. 86. 
Roland Boer distinguishes between formal and actual freedom to explain how Calvin linked spiritual and temporal freedoms. ${ }^{35}$ Formal freedom is a limited and constraint freedom and is contextual. ${ }^{36}$ In a sports match participants are free to strategise and use their skills within the confines of both rules and physical boundaries in a given situation, i.e. a sports match. Actual freedom provides human beings with the opportunity to make choices and to take action with the aim to re-create the situation itself. ${ }^{37}$ Christian freedom from the law, compulsion and external observances opens the possibility to work towards the removal of structures and systems that create un-freedom based on the premises that we belong not to ourselves but to God and to one another.

'Liberating' in the title then refers to this process through which social contexts are re-created to provide human beings, both as social groups and as individuals, the opportunity to improve their life chances ${ }^{38}$ by making choices that they can value. ${ }^{39}$ Polanyi argued that subjecting social systems to the economy prevents the majority of humans from making these choices. This injustice compels Reformed theology to consider the structural relationship between the economy and community. Bringing the old to an end to re-create the new ${ }^{40}$ represents a revolutionary freedom that is rooted in the freedom humans receive in Christ. In Reformed theology this freedom is expressed in the life before the Sovereign God, in covenantal intimacy with God, and from the just providence of God. ${ }^{41}$ Sovereignty, covenant and providence can also address the concerns of a social-embedded framework to integrate the economy into social contexts,

35 Boer, Political Grace, p. 128. He took this distinction from the thoughts of Lenin.

36 Ibid., p. 128.

37 Ibid., p. 128.

38 This concept is used by: J. Seekings, Continuity and Change in the South African Class Structure Since the End of Apartheid, CSSR Working Paper (Cape Town: University of Cape Town, 2015), p. 2.

39 Sen, Development as Freedom, pp.14-15.

40 Boer, Political Grace, p. 129.

41 This freedom is expressed in the life before the Sovereign God (Faciem Dei Contemplari), the covenantal intimacy with God (Sursum Corda), and the just providence of God (Iustitiae Amor).See: D.J. Smit, "Wie is ons? - oor ons Gereformeerde identiteit" (paper presented at the Excelsus se Sesde Lentekonferensie, Universiteit van Pretoria, 22 September 2011), p. 1. 
for responsibility and accountability in social relations and for ensuring access to livelihoods. The sovereignty of Christ is a confession that neither political or social, nor economic life forms independent spheres, but that political and economic life nor institutions are subjected to the mission of Christ. Covenant embeds human life and community in a context of responsibility and accountability in relationships that cannot allow individual or narrow interests to ignore the well-being other human beings. The confession that God is the providing One is a confession that humans are material beings that require material means and livelihoods to sustain human life in an interdependent process.

However, concepts such as sovereignty, covenant and providence can be dangerous and can serve not only to accentuate power and domination in political and economic life. They limit the possibility of making choices that could change the social context. ${ }^{42}$ This interpretation can be avoided when we understand that all three concepts have their origin in the initiative of God. God embraces the nations in true solidarity with them and establishes new social patterns of integration, togetherness, and interdependence.

The theological concept of covenant emphasises the freedom of God to initiate a new relationship with human beings to free humanity, and not only some individuals, or an institutionalised community of believers. Polanyi pointed out that a free market economy replaced the noncontractual relations such as kinship and tribe with contracts between individuals. ${ }^{43}$ Economic interests led to the alienation of the members of society, and organised society as contractual relations between two classes, between producers and customers, between owners and workers, and between sellers and buyers. ${ }^{44}$ These contractual relations were, however, not equal. ${ }^{45}$ Inequality became the new relational pattern that defined society. Covenant resists reducing relationships to contractual relationships. It opened the way to a new anthropology in which humans became economic beings (homo economicus) rather than relational beings. Covenant resists reducing relationships to a contractual relationship

42 J.B. Elshtain, "Sovereignty, Identity, Sacrifice", Social Research 58, no. 3 (1991), p. 557.

43 Polanyi, The Great Transformation, p. 171.

44 Pieters, 'Community and the Economy', p. 81.

45 Ibid., 81. 
because as human beings we are all called to enter into a relationship with God and with one another. ${ }^{46}$ Being human in a covenantal community not only transcends all differences between people and prevents justifying differences between human beings and condoning discriminating systems. Covenantal community also affirms the individual as a person that forms part of a network of non-contractual relations and thus as one that is free in community with others. God embraces the nations as God in community, and establishes freedom in community.

The emergence of contractual relations separated the economy from the political or social context. It means that the sovereign state became less a sphere of political power than one of economic power employing political and military power to its own advantage and to suppress any form of resistance and threat. The sovereign state prioritised economic interests and accumulation over sustaining social structures of care such as family and tribal relations and access to the means of livelihoods. Political economist Jean Bethke Elshtain identified a social network patterned on relational and interdependent togetherness as an alternative to interpreting sovereignty as power and domination. ${ }^{47} \mathrm{~A}$ relational and interdependent identity requires an ethic that, 'means one is answerable, accountable to another' and 'capable of fulfilling an obligation or trust.' ${ }^{\text {' }}$ Against this background, the sovereign rule of Christ becomes the foundation for human existence in an interdependent community of mutuality and responsibility. LenkaBula argued that God in Christ is the true sovereign One who brings shalom and protects life or re-creates the structures of care destroyed by power and domination. LenkaBula then adds that understanding wealth and accepting the responsibility that comes with it requires an understanding of the economy as the provision of the material means to satisfy human need and desire. ${ }^{49}$ Embracing the poor means to respond to their needs

46 See for instance Polanyi, The Great Transformation, p. 268.

47 Elshtain, 'Sovereignty', 563.

48 Ibid., 561.

49 P. LenkaBula, "Poverty, Wealth, and Ecology Viewed from African Feminist, Christian Political and Economic Ethics" World Council of Churches). [Online] Available: https://www.oikoumene.org/en/resources/documents/wcc-programmes/public-witness-addressing-poweraffirming-peace/poverty-wealth-and-ecology/neoliberal-paradigm/poverty-wealth-and-ecology-viewedfrom-african-feminist-christian-political-and-economic-ethics/@@download/file/PWE_June2007_Puleng. pdf, 14. 
through self-sacrificing grace. The notion of embracing the poor provides a solid theological ground to consider the concept of botho/ubuntu as a possible expression of the way social relations between human beings and communities in post-apartheid South Africa could ensure the provision of livelihoods. LenkaBula argued that the concept of botho can protect us against an anthropocentrism which destroys the ecological webs of life that consist of human beings and the ecological environment. ${ }^{50}$

The concept providence provides us with a new pattern for embracing the poor. The problem of providence is individualism that alienates humans and excludes some from access to livelihoods and the means for a life of dignity and freedom. Individualism interprets ownership as a sanctioning of the individual right and power to control, affirms the myth of deserving diligence and an obsession with the accumulation of wealth. ${ }^{51}$ Individualism justifies power and domination over workers and other marginalised groups. In the Reformed tradition, the doctrine of the providence of God is both practical and existential. ${ }^{52}$ God provides on a practical level to the point where everything that happens could be ascribed to the work and the will of God. ${ }^{53}$ By providing land, God provides not only food, but also security and habitation, or safety and creative space. Similarly, the opportunity to work is more than earning a wage. Both land and labour are mechanisms of care. The existential element of providence is a deeply eschatological insight that resists individualism and emphasises the human agent in the current and future work of God. ${ }^{54}$ It compels human beings to work creatively and in relational togetherness towards every form of justice and freedom. ${ }^{55}$ Human agency accentuates that the economy is an institutionalised process of responsibility that, given the

50 P. LenkaBula, 'Beyond Anthropocentricity - Botho/Ubuntu and the Quest for Economic and Ecological Justice in Africa.,' Religion \& Theology 15 (2008), p. 385-386.

51 Polanyi, The Great Transformation, p. 76.

52 J.J.F. Durand, Skepping, Mens, Voorsienigheid, Wegwysers in die Dogmatiek (Pretoria: NG Kerkboekhandel, 1982), p. 63.

53 Durand, „Skepping, Mens, Voorsienigheid“, p. 64.

54 Ibid., p. 63.

55 The confession of Belhar highlights the importance of this focus on humanity when it asserts that God is in a very special way the God of the poor and oppressed etc. URCSA, 'The Confession of Belhar' (Bellville URCSA). [Online] Available: http://www.vgksa.org.za/ documents/The\%20Belhar\%20Confession.pdf [Accessed 24 November 2016]. 
reality of disembeddedness, requires intervention in the production and distribution processes to ensure freedom for all and the sustainability of the means for an interdependent existence.

Reformed Christians understood that this liberating activity is the initiative of Christ, who is continuously renewing his world, exposing injustice through his grace, and re-creating social contexts through the combined action of his body. ${ }^{56}$ Through them, Christ changes policies, affirms and frees humans to let go of the desire to possess, and casts before them a vision of justice and fair life chances. Embracing the nations as partner means not only that human beings are created in the image of God, but also that we are all members of a common household and economy. ${ }^{57}$

Brueggemann wrote that ' $\mathrm{i}$ ]t is central to covenant that this One [Godself] cannot embrace without being transformed by the ones who are embraced ... embracing a partner is not an after-thought, but it is definitional for God. ${ }^{58}$ Living in solidarity with others transforms both the embraced and the one embracing and re-creates social contexts. ${ }^{59}$ Understanding covenant, sovereignty, and providence as the initiative of God on behalf of humanity reveals the revolutionary character of God. The initiative of God articulates how the sola gratia inspires the liberating capacity of Reformed theology. Piet Naudé is correct in asserting that redistributive justice is the true test for the sola gratia. ${ }^{60}$

\section{A church theology of economics?}

The discovery of the liberating capacity of the Reformed tradition also reveals a crucial weakness in the process the DRC followed in creating

56 D.J. Smit, "Reformed Ethics and Economic Justice?" in Essays in Public Theology. Collected Essays 1, ed. Ernst M. Conradie (Stellenbosch: SUN Press, 2007), p. 395.

57 W. Brueggeman. "From Anxiety and Greed to Milk and Honey. Biblical Faith Invites Us out of Self-Destruction toward God's Generosity and Abundance.", Sojourners) [Accessed on 20 May, 12 September 2016], p. 6.

58 W. Brueggeman, 'Covenant as a Subversive Paradigm,' The Christian Century. [Online] Available: http://www.religion-online.org/article/covenant-as-a-subversive-paradigm/ (1980). [Online] Available: http://www.religion-online.org/article/covenant-as-a-subversive-paradigm/2.

59 Boer, Political Grace, pp. 88-92.

60 P.J. Naudé, "We Cannot Just Continue as if Nothing has Happened Between Us. Sola Gratia and Restorative Justice," Scriptura 82 (2003), p. 171. 
the discussion document - the absence of engagement with the poor and women. The DRC's discussion document is mainly a report on a discussion with mainstream economists and political economists. The absence of engagement in the consultation process with representatives of the poor, of social movements such as student leaders and homeless associations, with women, as well as with representatives of social and solidarity economy movements is revealing of the embeddedness of white Reformed communities in a middle-class to upper-class existence. ${ }^{61}$ Engaging these groups as part of the consultation process can help the church to witness the economy from a deeper understanding of the complexities of the human condition in contexts of poverty and inequality and to unmask the underlying assumptions and asymmetric power structures.

By not engaging the marginalised an even more fundamental challenge to the DRC's theological foundation is revealed. Missional theology implies a commitment to a kingdom imagination of a world where humans can flourish. ${ }^{62}$ The concept of 'human flourishing' is problematic as flourishing is often associated with an improvement in life chances that is dependent on access to the necessary material means to facilitate the improvement. Education, healthcare, recreational activities, and housing are examples of how quality is dependent on access to material means. The notion of 'human flourishing' with its emphasis on comparison and standards creates images presenting conventional social patterns as normative. In the end, it reduces solidarity with the poor to an invitation to participate in the conventional economy and justifies dependence on economic growth. Rieger argued that while the focus on relationships in mission is important, it still harbours an expectation that 'the other' should conform to the asymmetric power system inherent to the conventionalist paradigm. ${ }^{63}$ It

61 J.W. De Gruchy, “Toward a Reformed Theology of Liberation: A Retrieval of Reformed Symbols in the Struggle for Justice," in Toward the Future of Reformed Theology, ed. David Willis and Michael Welker (Grand Rapids: William B Eerdmans Publishing Company, 1999), 107. Botha and Forster argued that the missional framework document does not give any indication of a real engagement with the particular context of the NG Church. J. Botha and D. Forster, 'Justice and the Missional Framework Document of the Dutch Reformed Church,' Verbum et Ecclesia 38, no. 1 (2017), p. 7.

62 NG Kerk, „Die N.G. Kerk en die Ekonomiese Ontwikkeling van ons Lande”, p. 15.

63 J. Rieger, "Theology and Mission between Neo- and Postcolonialism", Mission Studies 21, no. 2 (2012), p. 216. 
does not lead to spirituality where power and authority are relinquished to the 'other.' Missional theology is essentially a Church theology which is fundamentally informed by middle-class worldviews and interests. ${ }^{64}$ Therefore it cannot resolve the tension between freedom and solidarity.

\section{A possible response from the white Afrikaans Reformed Churches}

How can the white Afrikaans Reformed Churches begin to draw from the liberating patterns inherent to the Reformed tradition and imagine an economy that is embedded in an equal, just and free society?

An economic analysis from a social-embedded framework highlights that workers are not merely controlling processes of production on behalf of owners. They have a decisive participation in both the decision about and the execution of production and distribution. ${ }^{65}$ By participating in the economic process workers promote new forms of decision making and distribution of livelihoods in local communities. These new forms were suppressed by colonialism and its support for free-market capitalism. It is therefore essential for white South A fricans to understand decolonialisation as a process to 'open the door into another time' and not as an anti-West sentiment. ${ }^{66}$ It requires a process and programme intentional political and economic education in the DRC.

In the Reformed tradition, the transformation of human beings happens during a process of worship which consists of intentional listening and praying. ${ }^{67}$ For this to happen, the white Afrikaans Reformed Churches have to develop a new hermeneutic to read and understand the Bible as the book of the poor ${ }^{68}$ while we are consciously aware of our colonialist

64 Also see: J. Urbaniak, "Faith of an Angry People: Mapping a Renewed Prophetic Theology in South Africa," JTSA 157(2017): 7-43.

65 Dale, Karl Polanyi: The Limits of the Market, (Kindle Edition), loc 769.

66 L. Naidoo, "Hallucinations" (Johannesburg Wits Journalism) [Online] Available: http:// www.journalism.co.za/wp-content/uploads/2016/08/Leigh-Ann-Naidoo-Presentation.pdf [Accessed 6 November]. p. 2.

67 See: Smit, "Reformed Ethics", pp. 387-388. Smit discuss four aspects of Christian worship. These are subversion or liberation, formation, calling, and community.

68 P.J. Naudé, "In Defence of Partisan Justice - An Ethical Reflection on "the Preferential Option for the Poor"," Verbum et Ecclesia 28, no. 1 (2007), p. 171. 
and individualist paradigms. Could the biblical narrative of the prophet Jeremiah in his movement from a privileged member of society to a prophetic messenger and activist for the poor not provide the white Afrikaans Reformed Churches with a narrative to reform their participation in establishing freedom for all South Africans? Contextual Bible study has already shown that liberating hermeneutical models can only develop when we discover the potential of entering into a relationship of solidarity. Engaging the poor can help us to discover our enslavement to power, our unwillingness to relinquishing our position and assumed authority. ${ }^{69}$ The white Afrikaans Reformed Churches also face the challenge to maintain a relationship of solidarity with their current, mostly white, membership to discover the potential of accepting responsibility for reconciliation and restitution.

This process of discernment will have to consider and promote concrete action and the need for material restitution. It could help the church should they choose to engage in the movements of social and solidarity economics. ${ }^{70}$ Literature on social and solidarity economics indicates that the alternatives to extraction and growth economic systems are built on concepts linked to a liberating understanding of the notions of covenant, sovereignty, and providence. Social economy features initiatives such as redistribution of income within a market economy, different distribution systems, and patterns of integrating economics in specific social contexts and understanding the roles of economic role players differently ${ }^{71}$ to establish 'a collective well-being and re-create social bonds between the people within their communities. ${ }^{72}$ Solidarity economics emphasises cooperation above competition, relationships, and mutuality

69 “, pp. 220-1.

70 Shelley argued that 'solidarity economics is a fundamental theme that runs through both the Hebrew Bible, shared in part by the Jewish, Islamic, and Christian traditions, as well as the Christian New Testament.' B.G. Shelley, 'Reclaiming the Sabbath as a Vision of Solidarity Economics,' in Solidarity Economy I: Building Alternatives for People and Planet, ed. Emily Kawano, Thomas Neal Masterson, and Jonathan TellerElsberg (Amherst, MA USA: Center for Popular Economics, 2009), 139.

71 See F. Moulaert and O. Ailenei, "Social Economy, Third Sector and Solidarity Relations: A Conceptual Synthesis from History to Present”, Urban Studies 42, no. 11 (2005), pp. 2037-2038.

72 See Moulaert and Ailenei, 'Social Economy', p. 2041. 
above isolation, shared responsibility and accountability are emphasised above centralised decision making, diversity and localness above monoculturalism, and commitment to justice above accumulation. ${ }^{73}$

Social and solidarity economics suggest some economic strategies orientated to human relations rather than profit. These include the formation of worker, consumer and producer cooperatives; intentional communities, alternative currencies, community-run social centres and resource centres, community development credit unions (i.e. stokvels), community gardens, community supported agriculture (CSA) programmes, community-driven tourism, and community land trusts. ${ }^{74}$ The Broad-based Black Economic Empowerment (BBBEE) strategy of the South African government could potentially open possibilities to develop strategies orientated to human relations. Accepting and supporting strategies to promote the economic empowerment of the poor, to prioritise employment above mechanisation could all be meaningful ways for the white Afrikaans Reformed Churches to participate in the process of establishing an economic just and free society. However, as long as the white Afrikaans Reformed Churches do not prioritise the social context in their approach to the economy as a factor in social injustice and poverty the tension between unregulated freedom and solidarity will remain.

\section{Conclusion}

We should appreciate the willingness of the leadership of the DRC to engage the themes of economy and economic development. The current status of the discussion on economic development in the white Afrikaans Reformed Churches is still problematic in its focus on economic growth and the lack of engagement with the poor. It is also problematic that the missional foundation invites the poor to conform to conventional paradigms, rather than move the DRC membership to reach inward to participate in the

73 E. Miller, “Solidarity Economy: Key Concepts and Issues"” in Solidarity Economy I: Building Alternatives for People and Planet, ed. Emily Kawano, Thomas Neal Masterson, and Jonathan Teller-Elsberg (Amherst, MA USA: Center for Popular Economics, 2009), p. 25.

74 See: Miller, "Solidarity Economy: Key Concepts and Issues”, 25. 
life of Christ and through Christ in the life of the poor. ${ }^{75}$ Re-interpreting the notions of covenant, sovereignty and providence could provide white Afrikaans Reformed Churches with a framework to understand the work of God as work on behalf of humanity and to embrace the poor. It is through participating in the life of Christ that we receive the 'courage and strength to remove all removable injustice and unfreedom. ${ }^{37}$

\section{Bibliography}

Beckert, J. "The Great Transformation of Embeddedness: Karl Polanyi and the New Economic Sociology." In Discussion Paper 07/01, 5-23. Cologne: Max Planck Institute for the Study of Societies, 2007.

Block, F., and M. Somers. The Power of Market Fundamentalism: Karl Polanyi's Critique. Cambridge, Massachusettes: Harvard University Press 2014.

Boer, R. Political Grace. The Revolutionary Theology of John Calvin. Louisville: Westminster John Knox Press, 2009.

Botha, J., and D. Forster. "Justice and the Missional Framework Document of the Dutch Reformed Church." Verbum et Ecclesia 38, no. 1 (2017).

Brueggeman, W. "Covenant as a Subversive Paradigm." The Christian Century (1980): 1094-1099. [Online] Available: http://www.religion-online. org/article/covenant-as-a-subversive-paradigm/

Brueggemann, W. "From Anxiety and Greed to Milk and Honey. Biblical Faith Invites Us out of Self-Destruction toward God's Generosity and Abundance." Sojourners).

Dale, G. Karl Polanyi: The Limits of the Market. Cambridge; Malden, Mass.: Polity, 2010.

75 See: Rieger, “Theology and Mission”, 220-2.

76 Polanyi, The Great Transformation, 263. 
De Gruchy, J. W. “Toward a Reformed Theology of Liberation: A Retrieval of Reformed Symbols in the Struggle for Justice." In Toward the Future of Reformed Theology, edited by David Willis and Michael Welker. Grand Rapids: William B Eerdmans Publishing Company, 1999. 103-19.

Durand, J. J. F. Skepping, Mens, Voorsienigheid. Wegwysers in Die Dogmatiek. Pretoria: NG Kerkboekhandel, 1982.

Elshtain, J. B. “Sovereignty, Identity, Sacrifice." Social Research 58, no. 3 (1991): 545-64.

LenkaBula, P. "Beyond Anthropocentricity - Botho/Ubuntu and the Quest for Economic and Ecological Justice in Africa." Religion \& Theology 15 (2008): 375-94.

LenkaBula, P. "Poverty, Wealth, and Ecology Viewed from African Feminist, Christian Political and Economic Ethics." World Council of Churches). [Online] Available: https://www.oikoumene.org/en/resources/ documents/wcc-programmes/public-witness-addressing-power-affirming-peace/ poverty-wealth-and-ecology/neoliberal-paradigm/poverty-wealth-and-ecology-viewedfrom-african-feminist-christian-political-and-economic-ethics/@@download/file/ PWE_June2007_Puleng.pdf

Miller, E. “Solidarity Economy: Key Concepts and Issues." In Solidarity Economy I: Building Alternatives for People and Planet, edited by Emily Kawano, Thomas Neal Masterson and Jonathan Teller-Elsberg. Amherst, MA USA: Center for Popular Economics, 2009. 25-41.

Moulaert, F., and O. Ailenei. "Social Economy, Third Sector and Solidarity Relations: A Conceptual Synthesis from History to Present." Urban Studies 42, no. 11 (2005): 2037-53.

Naidoo, L. "Hallucinations." (Johannesburg, Wits Journalism). [Online] Available: http://www.journalism.co.za/wp-content/uploads/2016/08/Leigh-AnnNaidoo-Presentation.pdf.

Nattrass, N. "Controversies about Capitalism and Apartheid in South Africa: An Economic Perspective." Journal of Southern African Studies 17, no. 4 (1991): 654-77. 
Naudé, P. J. "In Defence of Partisan Justice - an Ethical Reflection on the "Preferential Option for the Poor."” Verbum et Ecclesia 28, no. 1 (12 Oct. 2011 2007): 166-90.

Naudé, P. J. "We Cannot Just Continue as If Nothing Has Happened between Us. Sola Gratia and Restorative Justice." Scriptura 82 (2003): 139-46.

NGKerk. „Besluiteregister Van Die Algemene Sinode 1994.“ Pretoria: Nederduitse Gereformeerde Kerk, 1994.

NGKerk. „Die N.G. Kerk en die Ekonomie - 'n prosesverslag.“ (Pretoria, Nederduitse Gereformeerde Kerk).

NGKerk. „Die N.G. Kerk en die ekonomiese ontwikkeling van ons lande.“ Pretoria: Nederduitse Gereformeerde Kerk, 2016.

NGKerk. „Handelinge van die Algemene Sinode 2007.“ Pretoria:

Nederduitse Gereformeerde Kerk, 2007.

Pieters, B. J. "Community and the Economy: A Reformed Theological Reflection on a Social-Embedded Economy." PhD, University of KwaZulu-Natal, 2016.

Polanyi, K. “The Economy as Instituted Process.” In Trade and Market in the Early Empires, edited by Karl Polanyi, Conrad M. Arensberg and Harry W. Pearson. Chicago: Free Press, 1957.

Polanyi, K. The Great Transformation. The Political and Economic Origins of Our Time. Boston: Beacon Press, 1944 (2001).

Polanyi, K. The Livelihood of Man. Edited by Harry W. Pearson New York: Academic Press, 1977.

Rieger, J. "Theology and Mission between Neo- and Post colonialism." Mission Studies 21, no. 2 (2012): 202-27.

Seekings, J. "Continuity and Change in the South African Class Structure since the End of Apartheid." In CSSR Working Paper, 1-34. Cape Town: University of Cape Town, 2015.

Sen, A. Development as Freedom. Oxford: Oxford University Press, 1999. 
Shelley, B. G. "Reclaiming the Sabbath as a Vision of Solidarity Economics." In Solidarity Economy I: Building Alternatives for People and Planet, edited by Emily Kawano, Thomas Neal Masterson and Jonathan Teller-Elsberg. Amherst, MA USA: Center for Popular Economics, 2009. 139-50.

Smit, D. J. "Freedom in Belonging?" In Essays on Being Reformed. Collected Essays 3, edited by Robert Vosloo. Study Guides in Religion and Theology 14. Publications of the University of the Western Cape. Stellenbosch: SUN MeDIA, 2009. 461-72.

Smit, D. J. "Reformed Ethics and Economic Justice?" In Essays in Public Theology. Collected Essays 1, edited by Ernst M. Conradie. Stellenbosch: SUN Press, 2007. 379-98.

Smit, D. J. "Wie is ons? - Oor ons Gereformeerde identiteit." In Excelsus se Sesde Lentekonferensie, 1-16. Universiteit van Pretoria: Excelsus, 2011.

Tanner, K. Economy of Grace. Minneapolis: Fortress Press, 2005.

Urbaniak, J. 'Faith of an Angry People: Mapping a Renewed Prophetic Theology in South Africa.' JTSA 157, no. March 2017 (2017): 7-43.

URCSA. 'The Confession of Belhar.' (Bellville, URCSA). [Online] Available: http://www.vgksa.org.za/documents/The\%20Belhar\%20Confession.pdf. 